\title{
Dividends, Return and Consumption
}

\author{
Malek Lashgari \\ University of Hartford
}

Based on empirical evidence, households consume dividends from common stock at a much higher rate than the rise in its price. This pattern is consistent with consumption from durable, predictable, and permanent sources of income as compared with non-durable income. Such a separate tracking of dividends and capital gains is not consistent with the notion of return as the combination of both: price appears to convey performance as compared to return. Empirical studies show that dividend yield predicts return in the short and the long horizons, particularly when the effects of repurchase activities as well as cash flow transfers to equity holders are included. The various empirical findings show, in part, that the market price of the stock does not decline as a result of the payment of cash dividend by as much as the elegant hypothesis of Miller and Modigliani implies. Behavioral finance provides some explanations in this regard as investors appear to view dividends as given, and place it in a mental account separate from the rise in price of the stock and not as an integral part of return.

Keywords: consumption, wealth, dividend policy

\section{INTRODUCTION}

Aggregate consumption is an important component of the Gross Domestic Product (GDP), and it is imperative to know the role of the financial side of the economy in funding a part of such expenditures. It has been documented that investor consume, with varying proportions, the periodic income generated from investments and the capital gain. That is, the Marginal Propensity of Consumption is different for regular income as compared to capital gain. And further Marginal Propensity of Consumption is different for the permanent and predictable sources of income as compared with the transitory or unpredictable source of income.

An investment in a financial asset, such as common stock, bonds, and real estate, generates a regular income which is generally known in advance. For example, a share of common stock provides dividends that is known for three months ahead with a stable trend within a short horizon. Thereby, investors may perceive dividends as a permanent or stable source of income. The same is the case for rental income in housing, or the interest coupon earned from bonds.

While investors may view dividends and capital gains differently and place them in separate pockets, it is important to consider both as the components of total return on investment. In effect, total return on investment in the long run includes not only the dividends received and the rise in price of the stock, but it is impacted by other factors as follows:

a. The additional benefit to the stockholders as a result of repurchasing the stock by the corporation from the market. 
b. The possible benefits to stockholders as a result of acquiring other businesses at a reasonable price with low-cost borrowing when the net cost of debt, after taxes, is less than the overall cost of capital to the corporation.

c. The change in the price of the stock caused by investors valuing the stock at a higher multiple of earnings. For example, if, on average, investors have applied 16 times expected earnings, but now they are willing to pay 20 times earnings, then there is a rise in total return as a result of the increase in the market value of the stock.

d. The possible dilution of earnings as a result of additions of new shares to the market by the corporation.

As the increase in wealth is as a result of the total return generated on its investments, and since the total return is measured by the inclusion, in part, of both dividends and capital gains, as noted above, it is important to know how individuals and institutions consume the resulting wealth: do they consume based on the average or expected return generated on investment; or do they view dividends as a free source of income to be spent, while carrying the accrued capital gain to preserve their wealth. We further need to know how individuals view the movements of the price of common stock after dividend is paid. That is, whether or not investors are aware that the price of the stock, theoretically, should fall by the amount of dividends, in the very short horizon, once dividends are paid.

This paper will provide a view on common stock valuation in part one; components of total return are shown in part two; related empirical studies on dividend payment are covered in part three; empirical evidence on consumption of dividends, capital gain and wealth is covered in part four; and conclusions follows.

\section{VALUATION OF COMMON STOCK}

Walter (1956) shows the value of the stock based on its stream of dividends and the reinvestment of the retained earnings as follows.

$$
\begin{aligned}
& V_{c}=\frac{D+\frac{R_{a}}{R_{c}}(E-D)}{R_{c}} \\
& V_{c}=\frac{E}{R_{c}}+\frac{R_{a}-R_{c}}{R_{c}^{2}}(E-D)
\end{aligned}
$$

Here, $V_{c}$, denotes the total value of the firm; D, denotes dividends; E, denotes earnings; (D-E), denotes retained earnings; $R_{a}$, denotes rate of return on additional investments by the firm; $R_{c}$, denotes the applicable discount rate to the company or the market capitalization rate and it is the return on investment that investors should earn, at the minimum, once they combine dividends and capital gain as the total return on investment.

According to this model, a dollar of retained earnings is equivalent to a dollar of dividend multiplied by $\frac{R_{a}}{R_{c}}$ and it will be worth more as long as $R_{a}$ is greater than $R_{c}$.

$R_{a}$ is a weighted average of return on additional investments overtime, $r_{1}, r_{2} \ldots$ with a diminishing return on investment.

In the presence of income taxes, or personal tax, $T_{p}$, and capital gain tax, $T_{g}$,

$$
R_{a}=\frac{1-T_{p}}{1-T_{g}} R_{C}
$$

Equation (3) shows that in the presence of differential taxes where personal taxes or taxes on the regular income is greater than taxes on capital gain, even if $R_{a}$, return on investment of retained earnings, is less 
than $R_{c}$, the return in the market or discount rate, retained earning will add to the value of the firm. The incremental value declines as we approach the equality as shown in eq. (3).

As for a numerical example: If $\mathrm{R}_{\mathrm{c}}$ is $10 \%, T_{p}$ is 0.37 , and $T_{g}$ is 0.20 , then $R_{a}=\frac{1-0.37}{1-0.20}(10)=$ $0.7875^{*} 10=7.88 \%$. That is, as long as return on additional investments is greater than $7.88 \%$, value is added to the firm even though investors in the firm may require, or should be provided with, $10 \%$ return. Note that in equation (1) with no taxes, if $R_{a}=R_{c}$, then $V_{c}=\frac{E}{R_{c}}$, that is, value of the firm is based on the discounted value of its earnings as stated by Miller and Modigliani (1961).

The role of dividends in valuation of the firm is further evident in the Graham and Dodd approach to value as shown in equation (4).

Value $=$ Multiple $\left(D+\frac{1}{3} E\right)$

where the multiple is the inverse of the capitalization rate, $\frac{1}{R_{c}}$. For example, if $R_{c}$ is $5 \%$, then the multiple is 20 , and Value $=20\left(D+\frac{1}{3} E\right)$. Thus, as shown in equation (4), value is a function of dividend and earnings, and common stock prices vary directly with dividend payout ratio, and care must be given to earn a satisfactory return on investment of retained earnings.

Gordon (1962) shows the value of stock as the discounted value of the stream of dividends as shown in equation (5).

$V_{0}=\frac{D_{0}(1+g)}{(1+k)}+\frac{D_{0}(1+g)^{2}}{(1+k)^{2}}+\cdots+\frac{D_{0}(1+g)^{n}}{(1+k)^{n}}$

Here, $V_{0}$ denotes value of common stock or $P_{0} ; D_{0}$ as the current dividend; $D_{0}(1+g)$ as expected dividend; and $\mathrm{g}$, is the constant growth in earnings, and $\mathrm{K}$, or $\mathrm{R}$ denote discount rates.

The Gordon model is summarized as shown in equation (6):

$V_{0}=\frac{D_{1}}{k-g}$ or $P_{0}=\frac{D_{1}}{R-g}$

Equation (7) shows Gordon model in its return form.

$K=\frac{D_{1}}{V_{0}}+g$ or $R=\frac{D_{1}}{P_{0}}+g$

Campbell and Shiller (1988), show the Gordon model in a log linear form, where: $h_{1, t}=\log \frac{P_{t+1}+D_{t}}{P_{t}}=\log \left(P_{t+1}+D_{t}\right)-\log P_{t}$ is the return for one year at time $\mathrm{t}$, and $h_{2, t}$ as the return over two years at time t, and so on, and $d_{t}$ as the log of dividend price ratio, or the dividend yield, as $\frac{D_{t-1}}{P_{t}}$; $d_{t}=\log \frac{D_{t-1}}{P_{t}}=\log D_{t-1}-\log P_{t}$ and $\Delta d_{t-1}$ as the lagged dividend growth rate in the $\log$ form. They further use $e_{t}$ as $\log \frac{E_{1}-1}{P_{t}}=\log E_{t-1}-\log P_{t}$ and use moving averages of 10 to 30 years.

Campbell and Shiller find that except for the dividend growth rate, the other variables have a good explanatory power of 30 to 65 percent over a 10-year horizon. Further, log of real dividend yield explains $26.6 \%$ of variance in real return over a 10-year horizon and the log of real earnings yield, explains $30 \%$ in a 10-year time. The log of 30-year moving average of earnings yield explains 57\% of variance in return. They conclude that the combination of log of real dividend yield, the growth in dividend, and 30-year moving average of log of earnings yield explains $63.7 \%$ of variance in the log of real return. Their study covered 1871-1987. 
As shown in Table 1, Cochrane (2011), utilizing the log linear Gordon model as developed by Campbell and Shiller (1988), shows that in a 1-year regression, one percentage point increase in dividend yield forecasts four percentage points higher return, prices rise by additional three percentage points, and expected return may vary by as much as 5.5 percentage points. The 5 -year regression shows that 1 percentage point rise in dividend yield corresponds with about 21 percentage points rise in return. Thereby, dividend yields forecast returns.

TABLE 1

RESULT OF REGRESSION OF RETURN ONTO THE DIVIDEND YIELD

\begin{tabular}{|l|c|c|c|c|c|}
\hline Horizon & $\mathrm{b}$ & $\boldsymbol{t}_{(\boldsymbol{b})}$ & $\boldsymbol{R}^{\mathbf{2}}$ & $\boldsymbol{S}\left[\boldsymbol{E}_{\boldsymbol{t}}\left(\boldsymbol{R}^{\boldsymbol{e}}\right)\right.$ & $\frac{\boldsymbol{S}\left(\boldsymbol{E}\left(\boldsymbol{R}^{\boldsymbol{e}}\right)\right)}{\boldsymbol{E}\left(\boldsymbol{R}^{\boldsymbol{e}}\right)}$ \\
\hline 1 Year & 3.8 & 2.6 & 0.09 & 5.46 & 0.76 \\
\hline 5 Year & 20.6 & 3.4 & 0.28 & 29.3 & 0.62 \\
\hline
\end{tabular}

\section{COMPONENTS OF RETURN}

According to the Gordon model for valuation of common stock, as shown in equation (6), and its resulting return, equation (7), we know that return is a combination of dividend yield and the growth in earnings, leading to a higher value in price; $R=\frac{D_{1}}{P_{0}}+g$. Here $\mathrm{R}$ denotes return; $\frac{D_{1}}{P_{0}}$ denotes dividend yield; and $\mathrm{g}$ is a proxy for capital gain. Grinold and Kroner (2011), and Arnott and Bernstein (2011), show a decomposition of return as follows.

$\left(\frac{D_{1}}{P_{0}}+\right.$ share repurchase effect - new share issurance effect $)+(g+i)+d\left(\frac{P}{E}\right)$

Here $\frac{D_{1}}{P_{0}}$ denotes dividend yield; i denotes inflation; $d\left(\frac{P}{E}\right)$ denotes the change or expansion in price to earnings ratio. A repurchase activity by the firm in buying its shares from the market tends to increase earnings per share. A share issuance has the opposite effect. The authors measure the effect of share buybacks and new share issuance as the difference in the changes in total earnings and the earnings per share. This is because, the growth in total earnings is unaffected by the number of shares outstanding. This is also revealed by observing the change in price versus the change in equity market capitalization. The capital gain includes growth in earnings, inflation, and the expansion in the price earnings ratio. The following shows an estimate during 1926-2010.

Income return: $1.78 \%$ for dividend yield; the addition of $2.2 \%$, for the repurchase effect; a decrease of $2 \%$ for new share issuance effect, will result in $1.98 \%$ for the income part of the return. As for capital gain, it includes an estimate of $1.8 \%$ for the growth in earnings, an adjustment for inflation of $2.4 \%$ was added and $0.85 \%$ was further included for the expansion in the price earnings ratio, resulting in $5.05 \%$ for the capital gain. Total return is thus $1.98+5.05=7.03 \%$.

Several studies show that the adjusted dividend yield, as the income part of the return, enhances its predictive power. For example, Boudoukh, Michaely, Richardson, and Roberts (2007), in support of the dividend yield or the income part of the return, find that repurchase as a percentage of dividends plus repurchase has risen from $5-15 \%$ in the 1980 s to above 50 percent in 2003 . The $R^{2}$ of regression of returns on dividend yield rises by 65 percentage points when repurchases plus dividends are used as compared to dividend.

In addition, Robertson and Wright (2006), further show the role of the income part of the return stating that cash-based and acquisitions that are financed by borrowing, as well as share repurchases, are sources of cash flow to stockholders. They show that during 1900-2002, the AR (1) coefficient for cash flow yield is 0.63 , while for dividend yield alone is 0.87 for the Standard and Poor's composite index. They conclude 
that the unit root restriction is strongly rejected for cash flow yield, but it cannot be rejected for dividend yield. They further show that while the cash flow yield to stockholders is more volatile than the dividend yield, it has a stronger mean reversion than dividend yield.

\section{The Payment of Dividend and Change in Price}

Miller and Modigliani (1961) prove that the market price of common stock declines by the amount of dividend paid and that investors should view a dollar in dividend and a dollar in the rise in price of stock as the same in maximizing their wealth. In other words investors should concentrate on total return, consisting of dividends and capital gains. In this context, a dollar in dividend and a dollar resulting from sale of the stock should be viewed the same, in the absence of differential taxes and transaction costs. Further, that the value of the stock depends on its earnings power and the applicable discount rate.

Nissim and Ziv (2001) find that changes in dividend payment convey information regarding future earnings in subsequent years, which will in turn, affect return. During their study horizon, 1963-1998, the average excess return, as defined by return minus CRSP equally weighted index, showed minus $4.97 \%$ for decreases in dividend and $0.87 \%$ for increase in dividend, and $0 \%$ for no change in dividend. The use of excess return as the return above prevailing return in the market conveys information about the future earnings of the firm, and thereby impacts its market value. This is consistent with Miller and Modigliani that value is determined by the earnings power of the firm. Their model is as follows:

$\frac{E_{t}-E_{t-1}}{B_{t-1}}=a_{0}+a_{1} \Delta$ divid $+a_{2} R O E_{t-1}+e_{t}$

Here E denotes earnings, B denotes book value, and ROE denotes return on equity.

Hartzmark and Solomon (2019), use data during 1980-2015 for common stock as well as trades for individual investors during 1991-1996, and find that during 1980-2015, the daily correlation between return and dividend yield is 0.09 , implying a decline in price slightly less than the amount of dividend paid.

TABLE 2

RELATIONS BETWEEN RETURN, PRICE, AND DIVIDEND YIELD 1980-2015

\begin{tabular}{|c|c|c|c|}
\hline & Daily & Monthly & Annual \\
\hline Average Return & 0.0008 & 0.0113 & 0.1601 \\
\hline $\begin{array}{c}\text { Average Percentage } \\
\text { Price change }\end{array}$ & 0.0007 & 0.0094 & 0.1340 \\
\hline $\begin{array}{c}\text { Average Dividend } \\
\text { Yield }\end{array}$ & 0.0001 & 0.0019 & 0.0242 \\
\hline $\begin{array}{c}\text { Correlation (Return } \\
\text { Dividend Yield) }\end{array}$ & 0.0061 & 0.0171 & -0.0097 \\
\hline $\begin{array}{c}\text { Correlation (Price } \\
\text { Change, Dividend } \\
\text { Yield) }\end{array}$ & -0.5039 & -0.1031 & -0.067 \\
\hline
\end{tabular}

As shown in Table 2, at the daily level, the correlation between the price change and dividend yield is negative 0.5039 implying that the price falls as dividends are paid. However, the correlation is not a negative one as stated by Miller and Modigliani. The correlation between price change and dividend yield on an annual level is negative 0.067 showing that correlation between price change and dividend yield approaches zero in the longer horizon. A negative correlation of 0.1031 is also sufficiently low for the monthly horizon. 


\section{DIVIDENDS, RETURN, AND CONSUMPTION}

Using trades by individual investors, Hartzmark and Solomon find that there is a lack of connection or integration between price changes and dividends. Investors consider price changes and dividends separately which is consistent with the mental accounting for dividend income and capital gain. Price changes are perceived as a measure of performance and highly noticeable, while dividends are considered as given. That is, investors do not combine the price change and dividend yield as an indicator of performance. The authors further note the disposition effect in the trading activities of investors as stocks with higher price appreciation are sold as the winning stocks with no consideration of total return, disregarding the dividend income part of the return. However, investors do not tend to sell stocks with a high dividend yield.

DiMaggio, Kermani, and Majlesi (2020), study the effect of changes in stock return on consumption and find that the rise in stock price leads to 23 percent increase in marginal propensity of consumption at the lower 50 percent of wealth and only $3 \%$ for the top 30 percent of wealth, and 7 percent at the top 50 percent. That is the marginal propensity to consume due to the rise in stock price, sharply decreases at the higher levels of wealth. However, the rate of consumption spending from the dividend income received, is significantly higher at all levels of wealth and is close to 60 percent. These results show that households view income from dividend and the rise in stock price separately. That is, whereas the rise in price and the dividend received are both components of total return, households' marginal propensity to consume does not appear to be a function of total return, as it is highly skewed towards the dividend income, and the authors view this as being consistent with the free dividend fallacy of Hartzmark and Solomon (2019). In other words, households treat dividend and capital gains as two separate sources of income and forming different mental accounts for each.

DiMaggio, Kermani and Majlesi's findings are further in line with the findings that marginal propensity to consume out of durable sources of income is 60 to 80 percent and for non-durable is about 20 percent. In this view, dividend is perceived as the durable source of income whereas capital gain or the rise in stock price is not. Their data were taken from the Sweden household wealth during 1999-2007 in which the wealth tax was applied.

Baker, Nagel, Wurgler (2007) find that consumption depends on the form of return and not its level. They use Consumer Expenditure Survey which is a cross section of hundreds of families' real and financial wealth per year. Data were taken for 1988-2001. They also used the data on dividends, capital gains and trading at a discount brokerage firm during 1991-1996. They use a regression of consumption expenditures onto the dividend yield and total return and show that coefficient of dividend income is much larger, positive, and robust. They find that the rate of withdrawals out of dividend income is much higher than the capital gain, as investors view dividend income as a predictable source of income. Interestingly, special dividends show a weaker effect on consumption as they are sporadic and unpredictable. The authors consider this as the effect of mental accounting.

The model used by Baker, Nagel and Wurgler is as follows:

$C=a+z+g R+d D+F$

Here $\mathrm{C}$ denotes consumption, $\mathrm{R}$ denotes return, $\mathrm{D}$ denotes dividends, $\mathrm{Z}$ denotes households' characteristics such as education, age, and family size, and F denotes financial variables such as income, and wealth. Data are in a matrix form, and regression for the first differences is used. Theyfind that the propensity to withdraw dividends for normal levels of annual income is 77 percent and for the highest level of income is 33 percent, whereas the propensity to withdraw from total return is only 2 percent. They also found that utilization of dividend income on spending on durable goods is 3 to 4 times greater than nondurables. Overall, the results show support for the formation of separate mental accounts for dividends and capital gain, as well as support for the permanent income hypothesis, as investors do not appear to view capital gain as a source of permanent income.

Another evidence regarding perceptions of investors about dividend and price as separate from total return is shown by Glaser, Iliewa, and Weber (2019), as they find that when investors are presented with 
information regarding price, they use the most recent value in their projection, whereas when investors are presented with information regarding return, they use the entire past information in their forecast of the next likely return.

The role of dividend in funding consumption is further shown by Lettau and Ludvigson (2001), noting that the logarithm of the ratio of consumption to wealth, $\log \left(\frac{c}{w}\right)$ is a good predictor of future stock return. This follows the Campbell and Mankiw (1989) findings that the log of consumption to wealth ratio predicts asset returns. In this context when asset returns are expected to be higher, investors will increase consumption above its normal trend. Assets are defined as the portfolio of financial assets and human capital. If there is no labor income, no human capital, aggregate consumption is equal to aggregate dividends.

Their methodology follows Campbell and Shiller's log linear Gordon model in return form as follows:

$C_{t}-W_{t}=E_{t} \sum_{i=1}^{\infty} \rho_{w}^{i}\left(r_{w, t+i}-\Delta C_{t+i}\right)$

Here $C_{t}-W_{t}=\log \frac{\text { Consumption }}{\text { Wealth }}$, similar to $\log \frac{\text { Dividend }}{\text { Price }}$, and $\rho$ is a discount factor, and $\mathrm{r}=\log (1+$ return).

Campbell and Shiler's log-linear form of the Gordon model is as follows.

$d_{t}-p_{t}=E_{t} \sum_{i=1}^{\infty} \rho_{a}^{i}\left(r_{a, t+j}-\Delta d_{t+j}\right)$

Here, return is measured as $r_{1, t}=\log \frac{P_{t+1}+D_{t}}{P_{t}}=\log \left(P_{t+1}+D_{t}\right)-\log P_{t}$ and the dividend yield $\frac{D_{t-1}}{P_{t}}$; $d_{t}=\log \frac{D_{t-1}}{P_{t}}=\log D_{t-1}-\log P_{t}$ and $d_{t}-p_{t}$ is the $\log$ of dividend to price ratio, and $\Delta d_{t+j}$ as the dividend growth rate in the $\log$ form, and $\rho$ is a discount factor.

Further support for the impact of dividend income on consumption is shown by Graham and Kumar (2006), who find that older and lower income investors tend to purchase stocks that have recently announced the payment of dividend and that investors in the lower marginal tax rates concentrate on high dividend yield assets. This finding ties dividends to consumption as well. In particular, investors have a tendency to consume dividend, but to postpone realizing capital gain in order to preserve the principal for minimizing regret. Further, investors in the lower marginal tax rates concentrate on high yielding stocks in support of Elton and Gruber (1970). Further, their results are consistent with Miller and Modigliani (1961) for the clientele effect based on age or income.

\section{CONCLUSIONS}

Ever since the elegant dividend irrelevancy hypothesis of Miller Modigliani (1961) scholars in finance have explored the issue. According to this hypothesis, the division of earnings into dividend payout and reinvesting the remainder has no impact on the value of stock as value is determined by the total earnings and the associated discount rate. In the world with various differential taxes, frictions in the financial markets, investor life cycle behavior, and variation in real and financial wealth holdings, empirical studies have flourished casting some light on this yet unresolved issue.

While reviewing such empirical studies, the issue at hand in this paper is to explain if the payment of dividend would affect consumption. It has been shown that consumption depends on disposable income, wealth, marginal propensity to consume out of wealth and income, among others. Investors appear to consume dividends received and the gain in their wealth with various proportions. Empirical evidence shows that investors significantly spend more out of dividends received as compared to the gain in the market value of their holdings. One by product of the empirical findings is that dividend is perceived as a 
source of permanent income. This behavioral pattern differs from the rational behavior in which consumption should follow total return or increase in wealth. Dividend yield, however, predicts future expected return. Thereby, the payment of dividend and its growth, as per Lintner's adjustment to expected earnings, would be constructive to the growth in expected return and consumption.

\section{REFERENCES}

Arnott, R. (2011). Equity Risk Premium Myths. In Hammond, Leibowitz \& Siegel (Eds.), Equity Risk Premium (pp. 71-100).

Baker, M., Mendel, B., \& Wurgler, J. (2016, March). Dividends as Reference Points: A Behavioral Signaling Approach. The Review of Financial Studies, 29(3), 697-738.

Boudoukh, J., Michaely, R., Richardson, M., \& Roberts, M.R. (2007, April). On the Importance of Measuring Payout Yield: Implications for Empirical Asset Pricing. The Journal of Finance, LXII(2), 877-915.

Campbell, J.Y., \& Mankiw, G. (1989). Consumption, Income and Interest Return, the Time Series Evidence. In O.J. Blanchard \& S. Fischer (Eds.), NBER Macroeconomics Annual. MIT Press, Cambridge, MA.

Campbell, J.Y., \& Shiller, R.J. (1988). Stock Prices, Earnings, and Expected Dividends. The Journal of Finance, XLIII(3), 661-676.

Cochrane, J.H. (2011, August). Presidential Address: Discount Rates. The Journal of Finance, LXVI(4), $1047-1108$.

DiMaggio, M., Kermani, A., \& Majlesi, K. (2020, December). Stock Market Returns and Consumption. The Journal of Finance, LXXV(6), 3175-3219.

Elton, E. (1999, August). Expected Return, Realized Return, and Asset Pricing Tests. The Journal of Finance, LIV(4), 1199-1220.

Elton, E.J., \& Gruber, M.J. (1970, February). Marginal Stockholders' Tax Rates and the Clientele Effect. Review of Economics and Statistics, 52, 68-74.

Glaser, M., Zwetelina, I., \& Weber, M. (2019, December). Thinking about Prices versus Thinking about Returns in Financial Markets. The Journal of Finance, LXXIV(6), 2997-3039.

Gordon, M.J. (1962). Savings, Investment, and Valuation of Corporation. Review of Economics and Statistics, 44(1), 37-51.

Graham, J.R., \& Kumar, A. (2006, June). Do Divided Clienteles Exists? Evidence on Dividend Preferences of Retail Investors. The Journal of Finance, LXI(3), 1305-1335.

Grinold, R.C., Kroner, K.F., \& Siegel, L.B. (2011). A Supply Model of Equity Premium. In Hammond, Leibowitz \& Siegel (Eds.), Rethinking the Equity Risk Premium (pp. 53-70).

Han, K.C., \& Khaksari, S. (1996, Winter). Dividends, Taxes, and Returns: Empirical Evidence. Quarterly Journal of Business and Economics, 35(1), 3-15.

Hartzmark, S.M., \& Solomon, D.H. (2019, October). The Dividend Disconnect. The Journal of Finance, LXXIV(5), 2153-2199.

Letau, M., \& Ludvigson, S. (2001, June). Consumption, Aggregate Wealth, and Expected Stock Returns. The Journal of Finance, LVI(3), 815-849.

Miller, M., \& Modigliani, F. (1961). Dividend Policy, Growth, and the Valuation of Shares. Journal of Business, (46), 97-113.

Nissim, D.N., \& Ziv, A. (2001, December). Dividend Changes and Future Profitability. The Journal of Finance, LVI(6), 2111-2133.

Poterba, J., \& Slemrod, J. (2007). The Effects of Dividend on Consumption, Comments and Discussion. Brookings Papers on Economic Activity, 2007(1), 277-291.

Robertson, D., \& Wright, S. (2006, February). Total Cash Flow to Shareholders, and Predictive Return Regressions. The Review of Economics and Statistics, 88(1), 91-99.

Walter, J. (1956, March). Dividend Policies and Common Stock Prices. The Journal of Finance, 11(1), $29-41$. 